\title{
Jan Dettmers*
}

\section{Job definitions and service behaviour. An investigation among technical service employees ${ }^{* *}$}

Service organizations try to control the service behavior of employees using formal guidelines, training and instructions. However, the specific actions that are performed during the service encounters are predominantly under the discretion of the individual frontline employee. Therefore, the employee's idiosyncratic perception of the job, the subjective job definition, may significantly influence the behavior shown in the service encounter. Based on existing approaches on job definitions with regard to proactive, citizenship, prosocial and safety behavior this paper proposes a method to assess the subjective customer related job definition of service employees in the technical industries. The results of a survey in 49 small technical service organizations indicate good psychometric properties of the measure. A second study including a survey in 20 service organizations and a customer survey reveals that the customer related job definitions of service employees are associated with the service behavior as perceived by the customers. The findings underline the importance of subjective job definitions of service employees for the achievement of effective service behavior. Assessing and changing customer related job definitions may be a promising way to improve service quality.

Key words: job definition, task redefinition, service interaction, service quality, customer related job definition (JEL: L84, M31, O14, O15)

* Prof. Dr. Jan Dettmers, University of Hamburg, Work-and Organizational Psychology, Von-Melle-Park 11, 20146 Hamburg, Germany. E-mail: Jan.Dettmers@uni-hamburg.de.

** This research was supported by the German Federal Ministry of Education and Research (FK 01HY0410.

Article received: June 20, 2014

Revised version accepted after double blind review: November 11, 2014. 


\section{Introduction}

The service employees' behavior in the service encounter plays a crucial role for the customer's perception of service quality. Service organizations try to control the service behavior of employees using formal guidelines, training and instructions. However, the specific actions that are performed towards the customer during the service encounter remain under the discretion of the individual service employee. Therefore, the individual's understanding of his or her own job should significantly influence the actual service performance. The aim of this paper is to propose a method to assess the customer related job definition (CRJD) of technical service employees and to demonstrate empirical evidence regarding the importance of CRJD for the customer perception of service quality.

Recent research has emphasized the importance of employees' subjective perceptions of their job. Studies have provided evidence that the way employees subjectively define their job - in terms of what is part of their job or not - has a significant impact on their work behavior (e.g. Chiaburu \& Byrne, 2009; Turnipseed \& Wilson, 2008; Parker, 2007; Grube \& Piliavin, 2000; Morrison, 1994; Callero, Howard, \& Piliavin, 1987). Particularly with respect to work activities that cannot be formally enforced or controlled by supervisors, scholars expected to see significant effects of subjective job definitions. Existing studies on proactive (Parker, Wall, \& Jackson, 1997), citizenship (Kamdar, McAllister, \& Turban, 2006; Morrison, 1994), prosocial behavior (Callero et al., 1987) evealed the importance of idiosyncratic job definitions for the execution of these mostly discrete behaviors.

In the presented studies, we apply the existing research findings on subjective job definitions to the domain of service work, specifically to the customer related behaviors of technical service employees. Though it has been widely acknowledged that the interaction between a single service employee and the customer is a key factor for successful service delivery, until now research has hardly addressed the question of how employees understand their job in this interaction. In the domain of technical service there is a rising claim that employees should expand their job definitions to adopt customer related tasks in addition to their technical core tasks (Houben \& Wuestner, 2014; Gordon, 2007). However, in many technical industries (e.g. trade work, IT services) professional identities still base on technical task accomplishment rather than on service behavior (Knutzen, 2002; Lahner, 2004). It cannot be taken for granted that all employees understand tasks such as asking for feedback or integrating the customer into the service delivery process as part of their job (Di Mascio, 2010). Rather, it can be assumed that there may be a considerable variation between technical service employees regarding the perceived responsibility for customer related tasks that may be a key factor for the overall service quality of the service organization. Assessing systematically the subjective job definitions of service employees with regard to customer related tasks can be a promising way to improve overall service quality in this sector in two ways: Firstly, assessing the subjective job definition of the existing staff and reporting the results in team meetings can be powerful tool for organizational development towards a more customer oriented climate. Secondly, assessing the customer related job definition may be a useful method when selecting new employees. 
In this paper we propose a method to assess Customer Related Job Definitions in the technical services. After outlining the existing literature regarding the importance of subjective job definitions we illustrate the development process of an instrument for assessing Customer Related Job Definitions. Two studies aim at testing the validity of the developed measure. While the first study examines psychometric properties and convergent validity using statistical links to external criteria, the second study analyzes the criterion validity by examining the effects of the employees' job definitions on expressed service behavior using company, employee and customer data.

\section{The job definition of employees}

Insights about how employees understand their jobs are crucial for the understanding of work behavior. Objectively, a job can be described in terms of single tasks that the jobholder is expected to perform (Ilgen \& Hollenbeck, 1991) and by its relational architecture that affect employees' interpersonal interactions and connections (Grant, 2007). Jobs may be formally defined by job descriptions associated with a specific formal position. These job descriptions may include a defined set of tasks that are considered to be part of the job (Hackman, 1969). The subjective understanding of the job, however, may differ significantly from the formal job description (Wrzesniewski \& Dutton, 2001). The assumption that workers redefine their job and hold an individual and idiosyncratic understanding of their job is broadly acknowledged in industrial psychology (Hackman, 1969; Ilgen \& Hollenbeck, 1991; Salancik \& Pfeffer, 1978). The tasks that are assigned to a person are not adopted verbatim, but are compared with personal beliefs, experiences, motives and needs. As a result, the assigned tasks are adjusted and adopted as owned tasks (Thibaut \& Kelley, 1959). This process results in a redefined job (Hackman, 1969). By redefining the job requirements in terms of single activities or tasks that have to be executed, individuals create different jobs for themselves within the context of defined jobs (Wrzesniewski \& Dutton, 2001). Role theory would consider job descriptions and formal guidelines as a source of role expectations that are perceived by the jobholder. In the process of role taking, however, multiple sources of role expectations - including the jobholder's view - are taken into account. The jobholder creates a subjective role that may differ significantly from the formal guidelines (Graen, 1976; Katz \& Kahn, 1978; Neale \& Griffin, 2006). It is this subjectively defined role that determines the actual behavior of employees (Katz \& Kahn, 1978).

In the literature there are many different conceptualizations of and denominations for the subjective understanding of jobs (e.g. Ilgen \& Hollenbeck, 1991; Parker et al., 1997; Morrison, 1994). In most conceptualizations the terms job and role are used interchangeable. Both expressions refer to the question, what has to be done at work by the single employee (Ilgen \& Hollenbeck, 1991). Using the term role orientation, Parker et al. (1997) describe the content of subjective job definitions in terms of problems, tasks, and competences an employee considers to be relevant to his or her job. A similar concept is proposed by Morrison (1994). Her concept of perceived job breadth focuses on citizenship behaviors that may or may not be considered to be part of a job. Wrzesniewski and Dutton (2001) describe the concept of job crafting as an active process of job redefinition. In this process, employees enlarge or restrict the physical 
boundaries of the job (Wrzesniewski \& Dutton, 2001) by altering the number or type of tasks they consider to be part of their job (Ilgen \& Hollenbeck, 1991). Based on these considerations, we define subjective job definition as a defined set of single tasks and activities that an employee subjectively considers to be part of his or her job. Tasks and activities not included in the subjective job definition would be considered to be "not my job" (Parker et al., 1997; Zmud \& McLaughlin, 1989).

\section{Job definitions and work behavior}

From a theoretical point of view it seems to be obvious, that the employee's job definition should impact his or her work behavior. An employee's work effort will be transformed into effective work performance if the employee has a clear idea about where to direct his or her effort (Porter \& Lawler, 1968). However, empirical evidence for the relationship between subjective job definition and work behavior is rare and mostly recent: Kamdar et al. (2006) show that employees show more organizational citizenship behavior when they define these activities as part of their work role. Morrison (1994) reveals that an employee's work behavior as perceived by their supervisor is directly related to the employee's perception of which tasks are part of the job. Similar results are found by Coyle-Shapiro et al. (2004), Hofmann, Morgeson, \& Gerras (2003), Howell \& Boies (2004), Parker (2007) and Tepper and Taylor (2003).

Parker (2007) and Morrison (1994) differentiate job definitions in terms of breadth. Employees with a very narrow job definition feel responsible only for their traditionally prescribed core tasks. A broad job definition would be indicated if an employee feels responsible for a wider range of activities, such as minimizing stocks, the functioning of team work, long-term problem solving, accident prevention, and business improvement. In a longitudinal study with 58 production workers, Parker (2007) shows that the breadth of job definition may predict the work performance of employees, as judged by their supervisor, 18 month later even when controlling for other predictors such as job aspiration, job satisfaction, and generalized self-efficacy (Parker, 2007).

\section{Customer Related Job Definitions (CRJD)}

According to Parker et al. (1997), job definitions require a referent. Job definitions must be analyzed within a specific context or focus. Studies on subjective job definitions so far have focused on proactive behavior (e.g. flexible role orientation; Parker et al., 1997), citizenship behaviors (e.g. perceived job breadth; Morrison, 1994) and safety behavior (Turner, Chmiel, \& Walls, 2005). Parker (2007) proposes other foci such as innovation behavior or managerial behavior. In this former case, one might assess the extent to which a subjective job definition incorporates being creative or doing other innovation related activities. In the latter case, one might be interested in the extent to which managers define their job in transformational terms (for example, do they see it as 'their job' to develop and inspire employees).

The focus for our study is customer related behavior. Depending on the specific type of service, an effective service interaction with the customer is characterized by a specific set of activities that are considered to be useful to provide service quality. The interactive behavior may include activities such as seeking feedback, explaining the 
service delivery process to the customer, informing the customer, asking about further needs or generally engaging in relational communication (Barnard, 2001; Bowen \& Schneider, 1985; Fischbach, 2003; Gittell, Weinberg, Pfefferle, \& Bishop, 2008; Grant, 2007; Johnson, 1996; Mohr \& Bitner, 1991; Rafaeli, Ziklik, \& Doucet, 2008; Weitz, 1978). Research and business magazines increasingly claim that technical employees should extend their work roles, adopting Customer Related tasks in addition to their technical core tasks (Buchanan \& McCalman, 1989; Duris, 2000; Gordon, 2007; Newman, 2003; Houben \& Wuestner, 2014). Managers emphasizes the importance of relationships with clients and customers (Cascio, 1995). Presumably, there is considerable variance between employees about which customer related tasks are part of the job or not (Di Mascio, 2010). Based on job theoretical (Hackman, 1969; Ilgen \& Hollenbeck, 1991) and socio constructivist approaches, such as job crafting (Wrzesniewski \& Dutton, 2001), we argue that service employees differ in the way they interact with customers as a function of their individual redefinition processes (Hackman, 1969). By redefining the requirements of their formal job, service employees develop an individual and idiosyncratic understanding of the actions to fulfill towards the customer (Wrzesniewski \& Dutton, 2001; Fischbach, 2003).

In this paper the subjective understanding of the requirements of a job with regard to customer interaction will be referred to as Customer Related Job Definition (CRJD). Accounting for similar approaches with regard to proactive behavior (Parker et al., 1997) or citizenship behavior (Morrison, 1994) employees' Customer Related Job Definitions can be differentiated in terms of breadth. For example, an employee who sees his or her job exclusively in terms of solving technical problems has a narrow job definition. By contrast, an employee with a broader job definition additionally feels concern for customer related tasks, such as asking about further needs, explaining the service delivery process to customers, or asking for feedback. We expect that the breadth of the service employee's Customer Related Job Definition results in an interactive behavior during the service encounter that is perceived by the customer, which in turn impacts the perceived service quality of service organizations (Brady \& Cronin, 2001). The first step to approach CRJD was to develop an adequate measure. This was conducted in study 1.

\section{Study 1: Assessing Customer Related Job Definitions Item development}

The method we used to assess the CRJD is based on previous studies on job definitions (e.g. Parker et al., 1997; Morrison, 1994; Ilgen \& Hollenbeck, 1991). Ilgen and Hollenbeck (1991) propose measuring the content of a job in terms of "task elements" (p.200). In this approach, individually perceived jobs are described in terms of single tasks that employees subjectively feel responsible for (Ilgen \& Hollenbeck, 1991). Parker et al. (1997) build on this approach, defining job definitions (or role orientations) in terms of problems, tasks and competencies an individual employee considers to be relevant to his or her job. In a study on citizenship related job definitions, Morrison (1994) submitted a list of activities to employees. Employees were then asked to classify each activity as either a part of their job or somewhat above and beyond the scope of their job. We followed these approaches by specifying a set of customer re- 
lated tasks and asking employees to what extent they consider these tasks to be part of their job. The first step of the scale development was to define the tasks that are important during service interactions in the specific context of technical service. To gain insight into the relevant customer related tasks of technical service employees, we conducted 60 interviews with supervisors and employees of 20 technical service organizations. We asked participants to indicate which tasks employees have to complete in the service interaction in order to optimally fulfill the customer needs. Based on the answers and a review of the service research literature, we generated a large number of tasks that were considered to be important for the delivery of effective service. We then asked supervisors and experts of the specific technical service branch to rate these tasks in terms of relevance for that specific context of technical service. From the sufficiently relevant tasks, we selected 9 tasks that focused on two important goals of effective service interaction: namely, creating transparency, integrating the customer into the service delivery process and engaging in relational communication (Bitner, Faranda, Hubbert, \& Zeithaml, 1997; Gittell et al., 2008; Gross \& Badura, 1977; Maas \& Graf, 2004; Mohr \& Bitner, 1991; Prahalad \& Ramaswamy, 2004; Houben \& Wuestner, 2014).

The selected tasks were summed to form a scale (see table 1). For each of these tasks or activities, employees were asked to indicate on a Likert scale from 0 ("not at all") to 3 ("completely") the extent to which they considered a specific task to be part of their job. To legitimate perceptions of non-concern, the instruction stated that some of these tasks might be of concern only to supervisors or colleagues. Employees were then also asked to indicate to what extent the task was of concern of the supervisor or other staff members. Figure 1 illustrates an item example.

Figure 1: Item example

To explain to the customer the technical works that have to be done...

\begin{tabular}{|l|c|c|c|c|}
\hline & Not at all & scarcely & partly & completely \\
\hline ...is part of my job & $\square$ & $\square$ & $\square$ & $\square$ \\
\hline $\begin{array}{l}\text {...is part of my colleagues/ } \\
\text { co-workers' job }\end{array}$ & $\square$ & $\square$ & $\square$ & $\square$ \\
\hline ...is part of my supervisors' job & $\square$ & $\square$ & $\square$ & $\square$ \\
\hline
\end{tabular}

\section{Scale validation procedure}

To test the psychometric properties and validity we submitted the developed questionnaire to technical employees of different technical service companies. The study was part of a broader research project that aimed at enhancing innovativeness and customer orientation of technical service organizations in the metropolitan region of Hamburg (Germany). The project consisted of assessing current efforts of technical service organizations with respect to innovation and customer orientation and to develop an owner-based intervention program. The participating organizations were recruited via disseminators such as chamber of commerce, chamber of trade and direct 
mail and telephone acquisition. Following this strategy we recruited 49 technical service organizations with 9 organizations participating in the intervention. In sum 374 technical employees completed the questionnaires which corresponded to a response rate within each organization between $37.5 \%$ and $100 \%$ (mean $=79.4 \%$ ). The employees could be differentiated for their formal position (foremen, technicians, trainees, office workers). As reported by supervisors in preliminary interviews foremen dispose of a wide set of formal responsibilities (also with regard to customers), while technicians and trainees had mainly executing functions. Examples of tasks that were assigned specifically to foremen by supervisors were coordinating the service job with the customer regarding the objectives and procedures, preparing quotations for customers or dealing with complaints. Office workers had no face-to-face customer contact and differed considerably from the technical employees with respect to their formal tasks and responsibilities.

Based on these considerations we assumed that differences in the formal position would correspond with differences in the formal job content (objective job). As another indicator of the objective job, we assessed the supervisor view to the employees' job. We submitted a questionnaire to the supervisors with the same set of tasks that had been used to assess the employees' subjective job definition. Supervisor then had to rate to what extent each task is part of each employee group in the organization (foremen, technicians, trainees, office workers). We used the formal position and supervisor expectations to estimate convergent validity of the subjective job definition measure. As outlined above we assume that employees within the same job and position may differ significantly in their understanding of the job. However, job theoretical approaches consider the objective job and the formal job description as the starting point of the redefinition process (Hackman, 1969). Moreover, it can assumed supervisor expectations regarding specific positions can be assumed to impact the individual understanding of the job (Katz \& Kahn, 1978) admitting the significant role of idiosyncratic redefinition processes. Based on these considerations we expected, that supervisor expectations and formal position would be related to the subjective job definition. Due to idiosyncratic redefinition processes, however, we expected only small effects.

\section{Results}

The mean values, standard deviations, and scale statistics of the developed measure of CRJD are shown in Table 1. Standard deviations above .87 for the single items indicate that the items provoke sufficiently different responses to differentiate between employees who feel responsible for a task and employees who do not feel responsible for the same task. The means for single items varied considerably, indicating that the different tasks were not equally considered to be part of the job by all employees. As an estimate of the internal reliability of the scale, the Crohnbach's alpha was .87. This result indicates that the scale captures a construct that reflects the overall breadth of the CRJD.

ANOVA with the formal position as the independent factor and CRJD as dependent variable indicated that the formal position is directly related to the assessed breadth of the Customer Related Job Definition $(\mathrm{F}=41.58, \mathrm{p}<.01$; Eta $=.27$; see Table 
2). As expected, foremen dispose of a significantly broader CRJD than technicians. Technicians on their turn have a broader CRJD than trainees and office workers.

Table 1: Item and scale statistics for the scale Customer Related Job Definition $(n=351)$

\begin{tabular}{l|c|c|c}
\hline \multicolumn{1}{c|}{ „It's my job“ (0-3) } & M & SD & r itta \\
\hline 1. To introduce customer into new products. & 1.33 & 1.05 & .61 \\
\hline 2. To explain an elaborated offer to the customer & .74 & .99 & .56 \\
\hline 3. To negotiate details of an offer. & .45 & .87 & .50 \\
\hline 4. To explain to the customer the technical works that have to be done. & 1.53 & 1.06 & .74 \\
\hline 5. To discuss with the customer the results to be achieved by the works. & 1.56 & 1.10 & .70 \\
\hline 6. To explain to the customer the work performed in detail. & 1.64 & 1.15 & .61 \\
\hline 7. To check with the customer, if all requirements have been fulfilled. & 1.88 & 1.08 & .58 \\
\hline $\begin{array}{l}\text { 8. To ask the customer for improvements that could be achieved by the service } \\
\text { organization. }\end{array}$ & .71 & .94 & .46 \\
\hline 9. To find an immediate solution in case of customer complaints. & 1.69 & 1.01 & .65 \\
\hline Total (Scale) & 1.28 & .72 & .87 \\
\hline
\end{tabular}

Table 2: Mean differences in Customer Related Job Definitions between employees of different positions $(n=339)$

\begin{tabular}{l|c|c|c}
\hline Formal position & Mean & SD & $\mathbf{n}$ \\
\hline Foremen & 2.16 & .62 & 29 \\
Technician & 1.39 & .59 & 204 \\
Trainee & .99 & .63 & 53 \\
Office worker & .69 & .70 & 53 \\
Total & 1.28 & .72 & 339 \\
\hline \multirow{2}{*}{ Pillai-Spur } & F=41.58** & & \\
& Eta $=.27$ & & \\
\hline
\end{tabular}

${ }^{* *} p<.01$

To test the link between individual CRJD and supervisor expectations regarding the employee group we conducted for the subsample of technicians multilevel analysis for the individual CRJD as level 1 dependent variable and the supervisor expectation from the organizations technicians as level 2 predictor. The analysis reveals a significant effect (Coeff. $=.22 ; \mathrm{SE}=.10 ; \mathrm{t}=2.28$ ) which, however, explains only a small amount of variance in the individual job definitions.

Summarizing the results it can be concluded we developed a measure for the CRJD in the specific context of technical service work. The results of the descriptive analysis indicate that the scale has adequate psychometric properties. The direction and size of statistical relationships between the individual CRJD assessed by selfreports and external criteria (formal position and supervisor expectation) indicate adequate convergent validity. 


\section{Study 2: Customer Related Job Definitions and service behavior}

\section{Aims and hypotheses}

The aim of the second study was to show that service employee's CRJD is an important impact factor for the expressed behavior during the service interaction. Prior studies (e.g. Chiaburu \& Byrne, 2009; Morrison, 1994; Parker, 2007; Turnipseed \& Wilson, 2008) have shown that job definitions do result in manifest behavior. We expected that the subjective job definitions of service employees would result in manifest service behavior that is perceived by the customer. The subjective job definition should impact the customer's perception single service employees but also the generalized perception of all service employees of the service organization. Our hypothesis, therefore, was:

H1: Service employees' customer related job definitions result in specific service behaviors that are perceived by customers.

\section{Procedure}

To test the delineated hypothesis we conducted a second employee surveys in technical service companies. The second survey took place six months later within 20 companies who also participated in the first survey. 90 technical service employees (Foremen and technicians) completed the questionnaires (Response rate 72.6\%). As mentioned above, 9 organizations participated in an interventions program. This took place between the first and the second study and aimed at improving innovativeness. The intervention did also included strategies to encourage employees to report particularities of the customer site in order to generate ideas for service innovation (Marggraf-Micheel, Bamberg, Dettmers, Stremming, \& Vahle-Hinz, 2010). ANONVAs for repeated measurements revealed that the intervention did not affect the employees CRJD.

About three weeks after the survey, a customer survey took place to assess the service employee behavior as perceived by customers. Questionnaires were administered to customers by service employees when finishing a complete service work order, along with the bill. An incentive was given in the form of a charity donation for each questionnaire submitted to the university institute. Customers could send the questionnaire directly to the university using a prepaid and addressed envelope. Following this procedure, we received questionnaires from 352 customers that were served by the 20 companies.

The customer perception of service employee behavior was assessed by a selfdeveloped customer survey questionnaire. For the 9 tasks that constituted the CRJD scale, customers were asked to what extent service employees had shown a corresponding performance (e.g. "The service employee explained to me which technical work has to be done in detail"). Table 3 shows the list of the items. Furthermore we asked customers with a single item to give a general judgment about the company's service quality. 
Table 3: Customer survey questionnaire scale of perceived service employee behavior $(n=352)$

\begin{tabular}{l|c|c|c}
\hline \multicolumn{1}{c|}{ Items: Perceived service employee Behavior (1-5) } & Mean & SD & rita \\
\hline $\begin{array}{l}\text { 1. The service employee discusses with me the results to be achieved by the technical } \\
\text { works. }\end{array}$ & 4.42 & 0.77 & 0.68 \\
\hline 2. The service employee explains to me an elaborated offer. & 4.21 & 0.89 & 0.70 \\
\hline $\begin{array}{l}\text { 3. The service employee explains to me, which technical works have to be done in } \\
\text { detail. }\end{array}$ & 4.47 & 0.75 & 0.67 \\
\hline 4. I can negotiate with the service employee the details of an offer. & 3.88 & 0.94 & 0.53 \\
\hline 5. The service employee introduces me into new products. & 4.31 & 0.83 & 0.63 \\
\hline $\begin{array}{l}\text { 6. When work is finished the service employee explains to me the work performed in } \\
\text { detail. }\end{array}$ & 4.36 & 0.79 & 0.69 \\
\hline 7. The service employee checks with me, if all requirements have been fulfilled. & 4.25 & 0.95 & 0.69 \\
\hline $\begin{array}{l}\text { 8. The service employee asks me for improvements that could be achieved by the } \\
\text { service organization. }\end{array}$ & 3.08 & 1.09 & 0.41 \\
\hline 9. The service employee finds an immediate solution in case of customer complaints. & 4.47 & 0.63 & 0.53 \\
\hline Total & 4.16 & $\mathbf{0 . 6 0}$ & .87 \\
\hline
\end{tabular}

The customer evaluations means were mostly in the upper half of the scale, with 4.16 $(\mathrm{SD}=.60)$ for the perceived behavior, $4.47(\mathrm{SD}=.62)$ for the evaluated service quality and $4.56(\mathrm{SD}=.58)$ on a scale from 1-5. This is a common result in customer surveys on service quality (Buttle, 1996). It's noteworthy that customers did not evaluate the behavior and service quality of single employees, but reported their perception of the summarized behavior of all employees involved in a single service job. Though in most cases the service work order only involved one employee, it was not feasible to allocate a customer evaluation directly to a specific employee but to the aggregated service employees' job definitions of the serving company.

\section{Analysis}

To estimate the relationship between service employees' CRJDs and the customer perceptions of service employee behavior, we aggregated the service employees' CRJDs at the organization level. We assumed that the aggregated subjective job definitions of all service employees in each organization would be a good proxy for the service employees' CRJDs that interacted with the customer during the service order. Before aggregating the service employee data at the organizational level we tested the agreement within the organization as a prerequisites for aggregation (James, 1982; Klein \& Kozlowski, 2000; LeBreton \& Senter, 2007). In the present study we found average or high level of agreement between technicians or foremen within the same companies $\left(r_{w_{g}(j)}=.75\right.$ for the technicians, respectively $r_{w g(j)}=.99$ for the foremen) but lower agreement $\left(\mathrm{r}_{\mathrm{wg}(\mathrm{j})}=.69\right)$ for all service employees (technicians and foremen). We considered the agreement as sufficiently high to justify aggregation (Bliese, 2000). To test the amount by which the organizations differed with respect to the CRJD of their service employees, we calculated intra-class correlations (ICC), comparing the between-company to the within-company variance (ICC-1; Shrout \& Fleiss, 1979). The 
ICC-1 was significant at .16. This value exceeds the ICC $<.12$ proposed by James (1982) that is necessary to justify aggregation.

After aggregating the service employees' subjective CRJD to the company level, we tested its statistical relationships to the customer perception. We conducted multilevel analysis with the customer perception of service employees' service behavior as a dependent variable. Before entering into the analysis company's aggregated CRJD as predictor of customer perceptions, we centered it around the grand mean.

\section{Results}

Table 4 shows the results of the multi-level analysis that was calculated to link the customer evaluations to the aggregated CRJD of service employees. Before analyzing this relationship in model 1 , we tested in model 0 how much of the total variance in customer evaluations was attributable to between-company variance. As indicated by the ICC(1), $28 \%$ of the total variance in customer evaluations of perceived service employee behavior was attributable to between-company differences. The values of model 1 - presented in table 4 - indicate that the aggregated CRJD may contribute significantly $(p<.05)$ to the variance of the perceived service employee behavior.

To analyze the importance of the perceived service employee behavior for the judgment of service quality we calculated Pearson correlation between the customer ratings. A correlation coefficient of $r=.53(\mathrm{p}<.00)$ between perceived service employee behavior and perceived service quality indicates that the perceived service employee behavior is highly related to the perceived service quality.

Table 4: Multilevel analysis results for perceived service behavior as dependent variable $\left(\mathrm{n}_{\text {level } 1}=352 ; \mathrm{n}_{\text {level } 2}=20\right)$

\begin{tabular}{|c|c|c|c|c|c|c|}
\hline \multicolumn{7}{|l|}{ DV: Perceived service behavior } \\
\hline & \multicolumn{3}{|c|}{ Model 0} & \multicolumn{3}{|c|}{ Model 1} \\
\hline & Est. & SE & $t$ & Est. & SE & $t$ \\
\hline Intercept & 4.14 & 0.08 & 52.74 & 4.14 & 0.07 & 57.62 \\
\hline \multicolumn{7}{|c|}{ service employee's Customer Related } \\
\hline Job Definition & & & & 0.42 & 0.16 & $2.58^{*}$ \\
\hline Level 1 intercept variance (SE) & & 0.27 & & & 0.26 & \\
\hline Level 2 intercept variance (SE) & & 0.10 & & & 0.08 & \\
\hline$-2^{\star} \log$ likelihood & & 567.19 & & & 563.10 & \\
\hline Differences of $-2^{*} \log$ & & & & & $4.09^{*}$ & \\
\hline
\end{tabular}

${ }^{*} p<.05$

\section{Discussion}

Theoretical assumptions and the results of prior studies about the impact of job definitions on work behavior suggest that CRJDs are an important factor for the service 
behavior of service employees. As shown in the case of flexible proactive behavior (e.g. Parker, 2007) or citizenship behavior (e.g. Morrison, 1994), the subjective understanding of the job is important for actual work behavior. Particularly for discrete work behavior, such as proactive behavior, citizenship behavior, as well as customer related behavior during customer interaction, the subjective understanding of the job is crucial.

This study confirms the importance of subjective job definitions and extends previous research on job definitions to the domain of technical service work. The results of study 2 indicate that Customer Related Job Definitions of the technical service employees are related to the service behavior as perceived by the customer. The results of both studies support the utility of the proposed method for the assessment of CRJD. Scale and item statistics of the developed scale of CRJD indicate good psychometric properties and the potential to differentiate employees with a broad CRJD from those with a narrow CRJD. Differences between employees groups and relationship to supervisor expectations of expectable size confirm the convergent validity of the measure. The revealed statistical relationship between service employees' CRJD and customer perceptions of service employee behavior supports the criterion validity. Based on the overall results, we conclude that the subjective CRJD of technical service employees can be measured with the proposed instrument and the results of measurement can predict the customer perception of service employee behavior a key factor for the success of the service encounter and the perceived service quality.

These results raise the question of what service organizations can do to enhance the breadth of service employees' subjective CRJD. The literature on job definitions emphasizes the impact of idiosyncratic beliefs and needs on subjective job definitions. One way to broaden the CRJD of employees might be to explicitly include important customer related tasks into job descriptions. Improving the communication of supervisor assignments could be another promising way. As Morrison (1994) states, an important management function should be to reduce the perception of "that's not my job" with respect to activities that are considered to be important. The findings presented in this paper are significant for service work and service organizations because they suggest a promising avenue for performance enhancement. Especially in technical service, it seems to be important that service employees consider not only their core technical tasks as part of their job, but also customer related tasks. Abstract attitudes such as customer orientation or service models, as proposed in other studies (Di Mascio, 2010; Rafaeli et al., 2008), may be difficult to address by interventions. Subjective CRJD may be easier to enhance. Job definitions can be broken down into single concrete tasks that employees may consider to be part of their job or not. This opens a focused way for reflection and change. Changing the way service employees see their jobs may be a way of enhancing service quality. Assessing subjective job definitions by the method presented in this paper and contrasting them with changing requirements might be a way to broaden subjective job definitions to enhance performance, whether with regard to service behavior, proactive behavior or citizenship behavior. Apart from organizational actions to increase the clarity of task assignments, in the long run, professional images or role schemata have to be addressed (Neale \& Griffin, 2006). Training for technical services as well as professional education should place more 
emphasis on customer interaction if there is a desire to integrate customer related tasks as a basic part of the job. Good examples for training improvements regarding relational issues can be found in curricula of medical and nursing schools, who explicitly include interactive competencies into professional education objectives (e.g. LCME, 2011; UMM, 2008).

\section{Limitations}

The study presented in this paper has strengths, such as the use of multiple methods and different sources. However, it also has some limitations. The study was conducted within a specific branch of technical service, mainly with private customers, which reduces the generalized application of the findings. For example, it may be possible, that in other branches (e.g. business-to-business service) the relation between broad CRJD and perceived service quality may be lower as clients put more emphasis on technical problem solving. The small sample size - particularly at the most important level of analysis (organization level) - limited the study's power to detect effects. Additionally, the management of the different levels of analysis on the relationships between employees' job definitions, customer perceptions, and employee behavior could be criticized. Since job definitions were assessed at the level of individual service employees, the individual data had to be aggregated before being related to customer perceptions. A further step toward improvement would have been to match customer perception to single employees. Unfortunately, this was not possible in this study. In our view, however, this weakness further emphasizes the significance of the presented findings. We expect that pair-wise matching would reveal even higher relationships between subjective CRJD and perceived service employee behavior.

Additional criticism could be aimed at the list of customer related tasks generated for the surveys. The tasks were selected for the specific context of the technical service investigated in the study. For other contexts, items would need to be adapted. As Parker (2007) pointed out, there is no "one-size-fits-all" method of assessing subjective job definitions. Questionnaires first have to be adapted to the focus of research. Since this study focused on customer related behaviors, the scale of CRJD focused on specific interactive service behaviors. For each focus, methods have to be adapted to the context in which the research takes place (Parker, 2007) and they will be different in other contexts (e.g. human services for nurses, doctors, etc.). However, the method presented in this paper is easy adaptable when a specific set of tasks, important in a specific context and affected by subjective job definitions, has been identified.

\section{References}

ABIM. (2011). Advancing medical professionalism to improve health care. Retrieved from www.abimfoundation.org

Barnard, A. M. (2001). Feedback seeking in customer service relationships. Louisiana State University.

Bitner, M. J., Faranda, W. T., Hubbert, A. R., \& Zeithaml, V. A. (1997). Customer contributions and roles in service delivery. International Journal of Service Industry Management, 8(3), 193-205.

Bliese, P. D. (2000). Within-group agreement, non-independence, and reliability: Implications for data aggregation and analysis. In K. J. Klein \& S. W. J. Kozlowski (Eds.), Multilevel theory, research, and methods in organizations: Foundations, extensions, and new directions (pp. 349-381). San Francisco: JosseyBass. 
Bowen, D. E., \& Schneider, B. (1985). Boundary-spanning-role employees and the service encounter: some guidelines for management and research. In J. Czepiet, M. Soloman, \& C. Surprenant (Eds.), The service encounter. Managing employee/customer interactions in service business (3rd ed., pp. 124-147). Lexington, MA: Lexington Books.

Brady, M. K., \& Cronin, J. J. (2001). Customer orientation - Effects on customer service perceptions and outcome behaviors. Journal of Service Research, 3(3), 241-251.

Buchanan, D., \& McCalman, J. (1989). High performance work systems: The digital experience. Surrey: Routledge.

Buttle, F. (1996). SERVQUAL: review, critique, research agenda. European Journal of Marketing, 30(1), 8-32.

Callero, P. L., Howard, J. A., \& Piliavin, J. A. (1987). Helping behavior as role behavior: Disclosing social structure and history in the analysis of prosocial action. Social Psychology Quarterly, 50(3), 247-256.

Cascio, W. F. (1995). Whither industrial and organizational psychology in a changing world of work. American Psychologist, 50(11), 928-939.

Chiaburu, D. S., \& Byrne, Z. S. (2009). Predicting OCB role definitions: Exchanges with the organization and psychological attachment. Journal of Business and Psychology, 24(2), 201-214.

Coyle-Shapiro, J. .-M., Kessler, I., \& Purcell, J. (2004). Exploring organizationally directed citizenship behaviour: Reciprocity or "It's my Job"?. Journal of Management Studies, 41(1), 85-106.

Di Mascio, R. (2010). The service models of frontline employees. Journal of Marketing, 74(4), 63-80.

Duris, R. (2000). Fix the customer, then fix the machine. Frontline Solutions, 1(10), 82.

Fischbach, A. (2003). Determinants of emotion work. Georg-August Universität Göttingen.

Gittell, J. H., Weinberg, D., Pfefferle, S., \& Bishop, C. (2008). Impact of relational coordination on job satisfaction and quality outcomes: a study of nursing homes. Human Resource Management, 18(2), 154171.

Gordon, M. (2007). Basic concepts can be foreign to new counter staff. Aftermarket Business, (3), 66-66.

Graen, G. (1976). Role making processes within complex organizations. In M. D. Dunnette (Ed.), Handbook of industrial and organizational psychology. Chicago: Rand McNally College Pub. Co.

Grant, A. M. (2007). Relational job design and the motivation to make a prosocial difference. Academy of Management Review, 32(2), 393-417.

Gross, P., \& Badura, B. (1977). Sozialpolitik und Soziale Dienste. Entwurf einer Theorie personenbezogener Dienstleistungen. In C. von Ferber \& F.-X. Kaufmann (Eds.), Soziologie und Sozialpolitile (pp. 361-385). Opladen: Westdeutscher Verlag.

Grube, J. A., \& Piliavin, J. a. (2000). Role identity, organizational experiences, and volunteer performance. Personality and Social Psychology Bulletin, 26(9), 1108-1119.

Hackman, J. R. (1969). Nature of the task as a determiner of job behavior. Personnel Psychology, 22(4), 435444.

Hofmann, D. A., Morgeson, F. P., \& Gerras, S. J. (2003). Climate as a moderator of the relationship between leader-member exchange and content specific citizenship: Safety climate as an exemplar. Journal of Applied Psychology, 88(1), 170-178.

Howell, J. M., \& Boies, K. (2004). Champions of technological innovation: The influence of contextual knowledge, role orientation, idea generation, and idea promotion on champion emergence. The Leadership Quarterly, 15(1), 123-143.

Ilgen, D. R., \& Hollenbeck, J. R. (1991). The structure of work: Job design and roles. In M. D. Dunnette \& L. M. . Hough (Eds.), Handbook of industrial and organizational psychology (pp. 165-207). Palo Alto: Psychologists Press.

James, L. R. (1982). Aggregation bias in estimates of perceptual agreement. Journal of Applied Psychology, 67(2), 219-229.

Johnson, J. W. (1996). Linking employee perceptions of service climate to customer satisfaction. Personnel Psychology, 49, $831-851$.

Kamdar, D., McAllister, D. J., \& Turban, D. B. (2006). “All in a day's work”: How follower individual differences and justice perceptions predict OCB role definitions and behavior. Journal of Applied Psychology, 91(4), 841-855.

Katz, D., \& Kahn, R. L. (1978). The social psychology of organizations. New York: Wiley.

Klein, K. J., \& Kozlowski, S. W. J. (2000). From micro to meso: Critical steps in conceptualizing and conducting multilevel research. Organizational Research Methods, 3(3), 211-236. 
Knutzen, S. (2002). Steigerung der Innovationskompetenz des Handwerks. Eine Studie am Beispiel des Installationshandwerks in Hamburg. Bielefeld: Bertelsmann.

Lahner, J. (2004). Innovationsprozesse im Handwerk. Merkmale und Determinanten handwerklicher Innovationsprozesse. Duderstadt: Mecke.

LCME. FUNCTIONS AND STRUCTURE OF A MEDICAL SCHOOL - Standards for accreditation of medical education programs leading to the M.D. degree (2011). Retrieved from http://www.lcme.org/functions.pdf

LeBreton, J. M., \& Senter, J. L. (2007). Answers to 20 questions about interrater reliability and interrater agreement. Organizational Research Methods, 11(4), 815-852.

Maas, P., \& Graf, A. (2004). Leadership by customers? New roles of service companies' customers. Zeitschrift für Personalforschung, 18(3), 329-334.

Marggraf-Micheel, C., Bamberg, E., Dettmers, J., Stremming, S., \& Vahle-Hinz, T. (2010). Kundenorientiertes Innovationsmanagement in Klein- und Mittelbetrieben. Zeitschrift für Arbeits- und Organisationspsychologie A\&O, 54(3), 131-141.

Mohr, L. A., \& Bitner, M. J. (1991). Mutual understanding between customers and employees in service encounters. Advances in Consumer Research, 18, 611-617.

Morrison, E. W. (1994). Role definitions and organizational citizenship behavior: The importance of the employee's perspective. Academy of Management Journal, 37(6), 1543-1567.

Neale, M., \& Griffin, M. A. (2006). A model of self-held work roles and role transitions. Human Performance, 19(1), 23-41.

Newman, D. (2003). Everyone should be selling. Landscape Management, 42(2), 14.

Parker, S. K. (2007). 'That is my job' - How employees' role orientation affects their job performance. Human Relations, 60(3), 403-434.

Parker, S. K., Wall, T. D., \& Jackson, P. R. (1997). 'That's not my job': Developing flexible employee work orientations. Academy of Management Journal, 40, 899-929.

Porter, L., \& Lawler, E. (1968). Managerial attitudes and performance. Homewood: Richard D. Irwin, Inc.

Prahalad, C. K., \& Ramaswamy, V. (2004). Co-creating unique value with customers. Strategy \& Leadership, 32(3), 4-9.

Rafaeli, A., Ziklik, L., \& Doucet, L. (2008). The impact of call center employees' customer orientation behaviors on service quality. Journal of Service Research, 10(3), 239-255.

Salancik, G. R., \& Pfeffer, J. (1978). A social information processing approach to job attitudes and task design. Administration Science Quarterly, 23(2), 224-253.

Shrout, P. E., \& Fleiss, J. L. (1979). Intraclass correlations: uses in assessing rater reliability. Psychological Bulletin, 86(2), 420-428.

Tepper, B. J., \& Taylor, E. C. (2003). Relationships among supervisors' and subordinates' procedural justice perceptions and organizational citizenship behaviors. Academy of Management Journal, 46(1), 97-105.

Thibaut, J. W., \& Kelley, H. H. (1959). The social psychology of groups. New York: Wiley.

Turner, N., Chmiel, N., \& Walls, M. (2005). Railing for safety: job demands, job control, and safety citizenship role definition. Journal of Occupational Health Psychology, 10(4), 504-12.

Turnipseed, D. L., \& Wilson, G. L. (2008). From discretionary to required: The migration of organizational citizenship behavior. Journal of Leadership \& Organizational Studies, 15(3), 201-216.

UMM. Graduate Medical Education - ACGME Competencies (2009). Retrieved from http://www.umm.edu/gme/core comp.htm

Weitz, B. A. (1978). Relationship between salesperson performance and understanding of customer decision making. Journal of Marketing Research, 501-516.

Wrzesniewski, A., \& Dutton, J. E. (2001). Crafting a job: Revisioning employees as active crafters of their work. Academy of Management Review, 26(2), 179-201.

Zmud, R., \& McLaughlin, C. (1989). That's not my job: Managing secondary tasks effectively. Sloan Management Review, 30(2), 29-36. 